\title{
TRUMP'S DECISION TO RECOGNIZE JERUSALEM AS ISRAEL'S CAPITAL: DOMESTIC MOTIVATIONS AND REGIONAL CIRCUMSTANCES
}

\author{
Yousef M. Aljamal*
}

\begin{abstract}
This paper addresses regional circumstances and domestic factors that led to the Trump's decision to relocate the US embassy to Jerusalem as well as responses to the United States move. The US move of relocating embassy from Tel Aviv to Jerusalem after recognizing it as the capital of Israel would be likely impossible without the existence of specific domestic circumstances as well as regional developments. Trump wanted to get the support of the pro-Israel Republicans, to appease his pro-Israel donors, to win the support of his evangelical base, and to over-shadow investigations against him in the US. The regional situation in the Middle East made making such a decision an easier task for Trump, with Palestinians divided, Arab governments more willing to accept Israel, and some already in the process of normalizing ties with it. Meanwhile, Arab countries are busy with their own domestic issues following the outbreak of the Arab Spring and civil wars in 2011. All these factors paved the way for Trump to break a taboo in the US foreign policy that was maintained by all former American presidents, many of them are supportive of Israel, thus angering Palestinians and pleasing Israelis.
\end{abstract}

Key words: Trump, Jerusalem, Israel, Palestine, US

\section{Introduction}

December 6, 2017 saw a radical shift in US policy towards the Middle East in general, and the Palestinian-Israeli conflict in particular, after Donald Trump's decision to recognize Jerusalem as Israel's capital. For decades, the US has served as a peace broker between the Palestinians and the Israelis to reach a solution to the long-standing conflict based on the two-state solution paradigm, which resulted in 1993 in the signing of the Oslo Accords, under US sponsorship. The Oslo Accords set out the framework for a solution based on two-states for two peoples, a Palestinian state living next to Israel based on the 1967 borders, with East Jerusalem as its capital. ${ }^{1}$ Although such a framework was not successful and never materialized, it remained the official framework for solving the conflict for the last 27 years of talks between the two parties.

Yet, Trump made it clear during his electoral campaign that he intended to recognize Jerusalem, instead of Tel Aviv, as the capital of Israel, unlike all former American presidents, and relocate the US embassy to the city, thus contradicting a tradition by all US presidents who had signed a decree putting off the implementation of moving the US embassy to Jerusalem, following a bill in the US congress in 1995 that called for doing so, to give a chance for peace talks between the Palestinians and the Israelis. ${ }^{2}$ Trump's decision was a radical shift in US policy towards Jerusalem which impacted the whole Middle East. Initially, Trump chose to sign a decree that put off moving the US embassy to Jerusalem for six months, but this didn't last long. Pressures by his campaign donors, such as Sheldon Adelson, started to mount and he had to make the ultimate decision and keep his promise to them in a move that surprised much of the world. ${ }^{3}$

Available literature on the Trump Jerusalem's move highlights the risks this move might cause in relation to US alliances in the region, which largely impacted the decision of former US presidents not to take such a move. ${ }^{4}$ Additionally, it explains the step from an international law perspective, explaining its illegality. ${ }^{5}$ In the same context, other scholars such as Hodkings noted that the Trump decision to

\footnotetext{
* Yousef M. Aljamal, PhD Candidate, Middle East Institute, Sakarya University, Turkey. ORCiD: https://orcid.org/0000-0003-0199-7159. Email: yousef.aljamal@ogr.sakarya.edu.tr.

${ }^{1}$ Dimitris Bouris (2010), "The European Union's role in the Palestinian Territory after the Oslo Accords: Stillborn state-building," Journal of contemporary European Research, Vol. 6, no. 3, pp. 376-394.

2 Basheer Al Zoughbi (2016), “Trump's Plan to Move the US Embassy to Jerusalem," Aljazeera Center for Studies, pp. 7-8.

${ }^{3}$ A. R. Moten (2018), "US Embassy in Jerusalem: Reasons, Implications and Consequences," Intellectual Discourse, Vol. 26, no. 1, p 13.

${ }^{4}$ S. Hamid (2017), The Jerusalem Announcement Won't Really Hurt America's Arab Alliances, Brookings Institution, December, 7.

${ }^{5}$ V. Kattan (2018), "Why US recognition of Jerusalem could be contrary to international law," Journal of Palestine Studies, Vol. 47, no. 3, pp. 72-92.
} 
move the US embassy in Israel to Jerusalem was the highlight of his foreign policy, in addition to other important issues such as North Korea, Russia, NAFTA, and the Paris Accords. ${ }^{6}$ Accordingly, this paper is trying to fill a gap in the available literature by looking at the move from the perspective of domestic motivations in the US and regional circumstances in the Middle East, which became ripe around the same time, allowing the US president to take such unprecedented decision.

This paper addresses this critical shift in the US foreign policy in the Middle East, particularly in relation to Israel/Palestine. It is of crucial importance to provide an analysis of this shift and the domestic as well as regional factors that existed both in the US and the Middle East that made it possible. By explaining these circumstances, the author aims to provide an answer as to how this US move was possible by looking at the sequence of events surrounding the issue of moving the US embassy to Jerusalem and the responses to the US move by both Palestinians and Israelis and the larger political changes in the Middle East that made some Arab governments more willing to accept such a move. Foreign Policy Analysis (FPA) is applied as an approach to better understand the motivations and circumstances surrounding the Trump's decision to relocate the US embassy from Tel Aviv to Jerusalem, which explains how decision-making and decision-makers are impacted when making decisions related to foreign policy. ${ }^{7}$

\section{Analytical Context}

Trump made it clear that his approach "marks the beginning of a new approach to conflict between Israel and the Palestinians," "referring to the Congress' adoption, in 1995, of an act calling on the US federal government to move the US embassy to Jerusalem. Yet, this act was always waivered by US presidential decrees under the belief that putting off recognizing Jerusalem as Israel's capital would serve an opportunity for peace. Trump added that his step, following decades of US waivers, would bring the Middle East a step closer to a lasting peace that would end the ongoing conflict between Israel and the Palestinians. He asserted that it is not wise to expect a different result when trying the same formula. ${ }^{9}$ There is much doubt that such a move would bring peace between the Palestinians and Israelis given how the Palestinians, both Muslims and Christians, view the city and the centrality of Jerusalem in the Arab and Muslim thought.

Keeping an electoral campaign promise, Trump announced that it was about time to recognize Jerusalem as Israel's capital, which has annexed eastern part of it in 1967. Trump has reversed a longstanding position by various US presidents not to move the embassy to Jerusalem, thus losing the Palestinians' confidence in the US as the official broker for peace talks between the Palestinians and Israel. In fact, moving the US embassy to Jerusalem was one of the pillars of Trump's foreign policy during his campaign, which made him win the votes of conservatives in the US as well as the pro-Israel lobbies. This move was at the expense of the US's relations with the Palestine Liberation Organization (PLO), which the US decided to shut down its Washington DC office under the claim that it refuses to achieve peace through negotiations. ${ }^{10}$ Not only this, the US decided to cut off aid given to UNRWA, the UN agency for Palestine refugees, in addition to aid given to the Palestinians through USAID, including critical aid given to hospitals in East Jerusalem. ${ }^{11}$

Trump claimed that his decision is long overdue, and that Israel is a sovereign country that could locate its capital as it wishes and deems appropriate. Trump asserted that Israel has the right, just like every other sovereign nation does, to do so, noting that acknowledging this right is an important condition to achieve a settlement between the Palestinians and Israel. However, there are many faults in this argument. First, the world's recognition of Israel as a country in 1948 was in the context of the Partition Plan and the UN Resolution 181, which called for establishing a Jewish and Arab states in Palestine and allowing Arabs to stay in the Jewish state and Jews to stay in the Arab State. Israel, however,

\footnotetext{
${ }^{6}$ A. Hodgkins (2017), Relocating the US Embassy in Israel: A cost benefit analysis for Trump administration. American Diplomacy, pp.1K$1 \mathrm{~K}$.

${ }^{7}$ M. Breuning (2007), Foreign policy analysis: A comparative introduction, New York City: Springer.

${ }^{8}$ White House (2017), "Statement by President Trump on Jerusalem," Statements and Release, the White House, Washington DC, 6 December 2017, https://goo.gl/R8opkp (accessed on 15 December 2019).

${ }^{9}$ White House (2017), "Statement by President Trump on Jerusalem."

${ }^{10}$ J. Galbraith (2019), "Palestine brings a case against the United States in the international court of justice at a fraught time for US-Palestinian relations," American Journal of International Law, Vol. 113, no. 1, pp. 143-149.

${ }^{11}$ J. Zanotti (2018), "US Foreign Aid to the Palestinians," Current Politics and Economics of the Middle East, Vol. 9, no. 4, pp. 731-766.
} 
prevented Palestinian refugees from returning back to their villages and cities in the newly established state of Israel. ${ }^{12}$ Second, under the UN Partition Plan of 1947, Jerusalem was designated as an international zone, and it was occupied by Israel respectively in 1948 and 1967. Thus, all Israeli actions and plans in the city are considered null and void under international law. The US's move means recognizing Israel's illegal control and annexation of Jerusalem, which contradicts various UN resolutions.

Trump noted that he gave instructions to the State Department to make the needed preparations to relocate the US embassy, yet ironically stressing that "a new embassy, when completed, will be a magnificent tribute to peace." 13 It is unlikely, based on the implications for such a move, that it would bring about security and peace in the region. Soon after Trump's recognition of Jerusalem as Israel's capital and his decision to move the US embassy to Jerusalem, hundreds of protests took place across the world. In the Palestinian territories, Palestinians clashed with Israeli forces which resulted in dozens of Palestinian deaths and hundreds of injuries. Legally speaking, under international law, an embassy is the symbol of sovereignty of a country and its building is considered part of the territory of that country, thus the US's embassy building would be considered placed in an area that is considered an international zone occupied by Israel according to the UN General Assembly Resolution 181, which the US voted in favor in $1947 . .^{14}$

Trump claimed that despite his decision to relocate the US embassy, it does not mean that this decision reflects a departure from the US commitment to brokering peace between the two parties. He explained that the US ultimately aims to reach an agreement, or a deal, as he puts it, between the Israelis and the Palestinians, that will be in the interest of both parties. Trump asserted that his government does not take positions regarding the final status issues, including Israel's borders in Jerusalem and the extent of its sovereignty there, including disputed borders. He noted that such issues are up to the Palestinians and Israel to decide on. ${ }^{15}$ In fact, such a statement contradicts the long-standing US policy. How would a peace broker recognize the future capital of a party involved in peace talks (Palestine) under its sponsorship as the capital of the other party involved in the peace talks (Israel), then claim that it is still committed to peace and asks both parties to continue peace talks? Trump's move meant that the US has taken a position regarding the conflict, by fully adopting the demands of the right-wing parties in Israel, which has for too long called for keeping East Jerusalem and the Jordan Valley under full Israeli control. ${ }^{16}$

The Trump Administration chose to shoot the two-state solution dead, which was not materialized for the last 27 years. It has recognized Jerusalem, the eastern part of which is supposed to be the capital of the future Palestinian state, part of Israel's capital. Thus, it would be better for Palestinians at this stage, after the failure of the two-state solution, to call for a solution based on equal human rights, rather than a solution based on borders, which was out of reach during the past three decades. Such a move would give a boost for those who have long called for one-state solution in Palestine, where all subjects living between the Jordan River and the Mediterranean would have equal rights, regardless of their religion and race. ${ }^{17}$ This view is shared by some Israelis as well, although small in number, such as journalist Zeev Sternhell, who wrote an article for the Israeli daily Haaretz Newspaper saying that Jerusalem, following Trump's decision, will serve as the basis for a binational state in historic Palestine, which includes both Israelis and Palestinians. ${ }^{18}$ The US recognition of Jerusalem has strengthened Israel's de facto control of historic Palestine. Yet, under this control, Palestinians are treated differently than their Jewish counterparts, regardless of where they live between the Jordan River and the Mediterranean.

\footnotetext{
12 The United Nations (1948), Israel membership in the UN - Letter from Israel. The United Nations: The Question of Palestine, 29 November 1948, https://www.un.org/unispal-/document/auto-insert-176869/ (accessed on 6 June 2020).

${ }^{13}$ Al Zoughbi (2016), "Trump's Plan to Move the US Embassy to Jerusalem," pp. 7-8.

${ }^{14}$ Khalidi Walid (1997), "Revisiting the UNGA Partition Resolution,” Journal of Palestine Studies, Vol. 27 , no. 1, pp. 5-21.

${ }^{15}$ Khalidi Walid (1997), "Revisiting the UNGA Partition Resolution," pp. 5-21.

${ }^{16}$ N. Habiballah (2016), “The Unmaking of Arab Jerusalem through Settlement Construction,” Jerusalem Quarterly, Vol. 65, pp. $111-117$.

${ }^{17}$ Ali Abunimah (2006), One Country: A Bold Proposal to End the Israeli-Palestinian Impasse, New York: Metropolitan Books, p. 15.

18 Zeev Sternhell (2017), "Jerusalem as the Basis of a Binational State," Haaretz Newspaper, Tel Aviv, 16 December 2017, https://goo.gl/x43Ww4 (accessed on 16 December 2019).
} 
It could be argued that Trump's interference in the Middle East has been different than any other American president as he shook the fundamentals of former US president's foreign policy in the region, introducing what Michalis Kontos referred to as the "Trump doctrine."19 The presidents of the US have always been supportive of Israel, as Israel is also a domestic issue in the US, but Trump has expressed support for Israel unconditionally. American presidents have always committed to supporting Israel and giving it a special package of military aid annually, the amount of which no other country in the world receives. Yet, Trump decided to directly get involved in the Palestinian-Israeli conflict, by making such a radical decision concerning Jerusalem as this move would boost his electoral base and enhance his chances of winning a second term. ${ }^{20}$

Although at the start of his campaign for US presidency, Trump told Jewish-American pro-Israel groups "I don't need your money," ${ }^{21}$ he shifted his discourse after he realized that his campaign will hardly survive without their support, aligning himself with the pro-Israel Republicans, especially Sheldon Adelson, who has donated tens of millions of dollars to the Trump campaign. ${ }^{22}$ Trump's move aimed to appeal to the key electoral districts, as well as the evangelical Christians. According to a poll conducted by the University of Maryland, which was published by the Brookings Institute, $52 \%$ of Republicans want the U.S. to lean toward Israel while $53 \%$ of Democrats believe Israel has too much influence in the US politics. ${ }^{23}$ Trump has repeatedly affirmed his support for Israel against the Iran nuclear deal which he called horrible and disastrous. He described the UN as unfriendly to Israel and threatened to withdraw US financial aid given to it, blaming the Palestinians for refusing Israel's many "generous offers," 24 referring to establishing a state on $22 \%$ of what used to be British mandate Palestine. The Palestine Liberation Organization (PLO) has accepted this proposal as a basis for ending the conflict, yet it was not materialized as Israel refuses to grant Palestinians a state on $22 \%$ of land or to allow Palestinian refugees to return.

In the United States, Trump is under domestic pressure after he and many of his presidential aides were investigated by the FBI over the role of Russia in the US elections. ${ }^{25}$ Trump made such a move to strengthen his domestic position by winning the support of some Americans who have social, political and economic interests with Israel. ${ }^{26}$ Moving the embassy was a political move (strengthening Trump's domestic position), a symbolic move against the Palestinians (recognizing the sovereignty of Israel), and a physical move (having an ambassador in Jerusalem, a ceremony, and a planned renovation of the Jerusalem site). Trump was persuaded to do so by Jared Kushner, among others, his Middle East advisor, and his son-in-law, who is also a personal friend of Benjamin Netanyahu, Israel's Prime Minister. Eli Clifton, an Israeli journalist stated that Trump's decision came following a pressure from his major electoral campaign contributor Adelson, who grew impatient of Trump's delays to make the long-awaited decision of recognizing Jerusalem as the capital of Israel. ${ }^{27}$ Owned by Adelson, The Las Vegas Review Journal noted: "The Adelsons reportedly have been disappointed in Trump's failure to keep a campaign pledge to move the U.S. Embassy to Jerusalem on his first day in office."28

Netanyahu, too, is being investigated by the Israeli police for corruption allegations. So, Trump's decision was a diversionary tactic for him to get rid of these allegations at home. Recently, he managed to form an Israeli government with Benny Gantz which he will preside for two years. ${ }^{29}$ The Israeli

\footnotetext{
${ }^{19}$ M. Kontos (2002), US Middle East Strategy under President Trump's Isolationist Foreign Policy, University of Nicosia.

${ }^{20}$ Rashid I. Khalidi (2018), “And Now What? The Trump Administration and the Question of Jerusalem," Journal of Palestine Studies, Vol. 47, no. 3, pp. 93-102.

21 Rayan Cooper (2019), "What Donald Trump Has Said about Jews," The Week, the United States, 18 April, 2019, https://theweek.com/articles/835714/what-donald-trump-said-about-jews (accessed on 17 May 2019).

${ }_{22}$ Mauro Lucentini (2016), “The Outlook for US Foreign Policy Under President Donald J. Trump," Rivista di Studi Politici Internazionali, Vol. 83 , no. 4 , p. 588 .

${ }^{23}$ Shibley Telhami (2018), "Why is Trump Undoing Decades of US Policy on Jerusalem?," The Washington Report on Middle East Affairs, Vol. 37, no. 1, pp. 8-13.

${ }^{24}$ Jacob Eriksson (2018), "Master of None: Trump, Jerusalem and the Prospects of Israeli-Palestinian Peace," Middle East Policy, Vol. 25, no. 2, pp. 51-52.

${ }^{25}$ Zoe Daniel (2017), "Donald Trump: The Huge Israel Announcement Has Overshadowed the Russia Turmoil at Home," ABC News Network, Sydney, Australia, 8 December 2017, https://goo.gl/jmyNdJ (accessed on 16 December 2019).

${ }^{26}$ Ian Black (2018), "Donald Trump and the Middle East," Political Insight, Vol. 9, no. 1, p. 25.

27 Eli Clifton (2017), "Is Sheldon Adelson Behind Trump's Decision on Jerusalem?" +972 Website, Tel Aviv, 5 December 2017, https://goo.gl/Umf6DK (accessed on 16 December 2019).

${ }^{28}$ Clifton (2017), "Is Sheldon Adelson Behind Trump's Decision on Jerusalem?"

${ }^{29}$ Oxford Analytica (2020), Gantz paves the way for an Israeli unity coalition, Emerald Expert Briefings.
} 
newspaper Haaretz noted that “The timing of Trump's announcement was good for Netanyahu, not only for reasons of state." ${ }^{\prime 30}$ According to the Newspaper, Trump's move helps Netanyahu distracts attention from the corruption investigations against him and his right-hand man David Bitan. ${ }^{31}$ So far, Netanyahu has survived legal cases against him because of his alleged corruption, but the more the US is willing to let him go on with his plans to annex more Palestinian lands, the better chances he gets to continue his political career.

Moreover, there are personal aspects to Trump's decision concerning Jerusalem. Sheldon Adelson reportedly met with Trump at his New York Tower ten days prior to his official inauguration and Adelson briefed the Zionist Organization of America about his plan to move the US embassy since the issue is "something that's in his heart and soul." 32 Adelson has given the Trump campaign a total of $21.5 \$$ million dollars in donations and Trump has finally decided to side with his supporters in the US as opposed to his Middle Eastern allies. He chose his evangelical base that saw a special connection with Jerusalem. ${ }^{33}$ Trump wanted to appeal to white Americans whose support for Israel has not eroded, compared to other segments of the American society. A poll by the Economist has revealed that support for Israel in the US is found mostly among Trump's base of voters. The poll revealed that $37 \%$ of those surveyed described Israel as an ally to the United States. This percentage was 19\% among African Americans, and $22 \%$ among Hispanics. ${ }^{34}$

\section{Responses to the US Jerusalem Move}

Following the Trump's campaign announcement that, if elected, he would move the US embassy to Jerusalem, the Palestinian National Authority (PNA) formed a committee called the National Committee against Relocating the U.S. Embassy to Jerusalem, warning that such a move "would be wrong, could have serious consequences and would constitute an act of aggression against the Palestinian people. ${ }^{" 35}$ Yet, this committee has not achieved anything tangible on the ground except for sit-ins and statements which many Palestinians feel fed up with. Many Palestinians today feel a lack of interest in the discourse presented by Palestinian factions especially following the rift between Hamas and Fatah in 2007, with the two groups unable to resolve their political differences and have a unified position.

In continuation of offering speeches to the Palestinians that lack a concrete action plan, the PNA President Mahmoud Abbas, said the US, by moving its embassy to Jerusalem, violates and contradicts international and bilateral resolutions and it contradicts what most world leaders agree upon over the issue of Jerusalem. He accused the US of killing peace and destroying all efforts made in this regard, thus withdrawing from its decades-long commitment as the major peace broker between the Palestinians and Israel. ${ }^{36}$ Abbas added that "such a move would not change the reality of Jerusalem and will not give Israel any legitimacy in this regard, as Jerusalem is a Palestinian, Arab, Christian and Islamic city, the eternal capital of Palestine. ${ }^{37}$ Abbas, as well as the Hamas government in Gaza, will not be able to do much to reverse the US decision. They have a limited influence over Arab governments, many of which are US allies, and they don't represent large segments of Palestinians, including those in the diaspora, given that the last Palestinian election took place in $2006 .{ }^{38}$

Abbas's discourse, albeit not his actions, expressed dismay at the US position, calling it a dishonest broker for a peace process that lasted too long, yet led to no tangible results. The Trump move had immediate implications in relation to the US-Palestinian relations. Abbas instructed PNA officials not

\footnotetext{
${ }^{30}$ Yossi Verter (2017), "With Jerusalem Recognition, Trump Gives Netanyahu a Great Tool to Distract the Masses," Haaretz Newspaper, Tel Aviv, 7 December 2017, https://goo.gl/eCUCH5 (accessed on 16 December 2017).

${ }^{31}$ Verter (2017), "With Jerusalem Recognition."

${ }^{32}$ Mark Landler (2017), "For Trump, an Embassy in Jerusalem Is a Political Decision, Not a Diplomatic One", New York Times, 6 December 2017, https://goo.gl/GD6iCD (accessed on 2 December 2019).

${ }^{33}$ Landler (2017), "For Trump, an Embassy in Jerusalem Is a Political Decision."

${ }^{34}$ Ali Abunimah (2018), "US support for Israel Eroding, But Not Among Trump Voters, Poll Finds," the Electronic Intifada, 26 October 2018 , https://goo.gl/Gn6RwC (accessed on 20 December 2019).

${ }^{35}$ WAFA (2017), "The National Committee: U.S. Embassy Move Is the Wrong Move," WAFA: Palestinian News and Info Agency, 19 January 2017, https://goo.gl/NkDt4A (accessed 16 April 2019).

${ }^{36}$ Masrawi News Website (2017), "Statement by President Abbas on Jerusalem," Cairo, 6 December 2017, https://goo.gl/tAC7zs (accessed on 16 December 2019).

${ }^{37}$ Masrawi News Website (2017), "Statement by President Abbas on Jerusalem."

${ }^{38}$ G. Usher (2006), "The democratic resistance: Hamas, Fatah, and the Palestinian elections," Journal of Palestine Studies, Vol. 35, no. 3, pp. $20-36$.
} 
to meet with the vice president of the US, Mike Pence, in protest of the US move, which resulted in US warnings and anger. The PNA's refusal to meet with Pence made him delay his visit to the region. Abbas's decision not to meet with Pence was unprecedented which reflects the anger of the Palestinian leadership in Ramallah over the US move. ${ }^{39}$ The US seemed to have lost its grip on the Palestine/Israel conflict after decades of sponsoring the peace talks between both sides. This could open the door for other superpowers such as Russia and China to propose themselves as brokers for peace between Israel and the Palestinians, thus harming the US strategic role as a peace broker for nearly three decades.

In the same context, Hamas, the largest Palestinian Islamist faction in the Occupied Palestinian Territories (OPTs), which rules the Gaza Strip, described the move as "a declaration of war." ${ }^{40}$ Hamas leader Ismail Haniya said the US decision will kill the peace talks as well as the whole Oslo Accords. He described the move as an "aggression" against the Palestinian people as well as Muslim and Christian holy shrines in Jerusalem. ${ }^{41}$ Haniya stressed that a new Palestinian Intifada should take place to confront the US move, adding, "We should work on launching an intifada in the face of the Zionist enemy." 42 The group, along with other Palestinian factions, has called for protests at the Gaza fence with Israel. ${ }^{43}$ Other than protesting at the Gaza fence, Hamas can't impact the discourse of actions in the OPTs, given the division between Hamas and Fatah. Additionally, Hamas is under siege and isolation in the Gaza Strip and it is classified as a terrorist group by the US, EU, Israel and is not favorable by many Arab governments. ${ }^{44}$

The reaction to the Trump Jerusalem move was not limited to Muslim figures and bodies. The leaders and patriarchs of churches in Jerusalem called on Trump to reverse his decision and urged that the international status of Jerusalem should be maintained. They sent a letter to Trump, in which they expressed their dismay at the US decision, noting that it will only bring about hatred, and conflict in the entire holy land... which will bring about more division in the region and make people a step away from peace. ${ }^{45}$ The position of the Jerusalem churches was also shared by the Coptic pope and Egypt's Grand Imam, who cancelled their scheduled meeting with the US vice president Pence over Jerusalem. ${ }^{46}$ The Coptic church said in a statement that "it excused itself from hosting" Pence when visiting the Egyptian capital of Cairo on December 20, adding that The US decision "did not take into account the feelings of millions of Arab people." ${ }^{, 47}$ Commenting on his refusal to meet Pence, Sheikh Ahmed al-Tayeb, the Grand Imam of Egypt was quoted as saying, "How can I sit with those who granted what they do not own to those who do not deserve?"48

The reactions to Trump's decision at the political, popular and religious levels were clear. It appeared as if ordinary people on the ground wanted to send a message of refusal to this move, urging the US to reverse its decision for the region not to enter in a state of conflict and turmoil. They wanted to inform the US that adopting such a new policy would have implications for the Arab/Palestinian-US relations. At the Arab and Muslim political level, most Arab and Muslim nations issued statements of condemnation for the US decision. So did European, African, Asian and Latin American nations, including the world's major powers, making the US look isolated, yet none of these positions and statements made the US change its position and peoples as well as governments didn't go beyond issuing statements or organizing sit-ins, which weakens their position and strengthens that of the US and Israel. ${ }^{49}$

\footnotetext{
${ }^{39}$ Gwen Ackerman \& Lin Noueihed (2017), "Pence Faces Difficult Middle East Visit After Jerusalem Move," Bloomberg, US, 9 December 2017, https://goo.gl/JAhNE7 (accessed on 16 December 2019).

${ }^{40}$ Aljazeera English (2017), "Hamas: US Decision on Jerusalem is A War Declaration," Aljazeera English, Qatar, 7 December 2017, https://goo.gl/JRQYCH (accessed 16 December 2019).

${ }^{41}$ Aljazeera English (2017), "Hamas: US Decision on Jerusalem is A War Declaration."

42 Aljazeera English (2017), "Hamas: US Decision on Jerusalem is A War Declaration."

${ }^{43}$ K. Belov (2018), "Running for human rights in Palestine," Green Left Weekly, Vol. 1202, p. 15.

${ }^{44}$ Y. M. Aljamal (2014), "Hamas: Terrorism Organization or Liberation Movement?," Политикологија религије, Vol. 8, no. 1, pp. $39-58$.

45 Tracy Wilkinson (2017), "Heads of Christian churches in Jerusalem Urge Retaining City's 'International Status'," Los Angeles Times, Los Angeles, US, 6 December 2017, https://goo.gl/SmQqw1 (accessed 16 December 2019).

${ }^{46}$ Aljazeera English (2017), "Egypt: Coptic pope cancels Pence Meeting Over Jerusalem,” Aljazeera English Network, Qatar, 9 December 2017, https://goo.gl/FLDuJw (accessed on 16 December 2019).

${ }^{47}$ Aljazeera English (2017), "Egypt: Coptic pope cancels Pence Meeting Over Jerusalem."

${ }^{48}$ Aljazeera English (2017), "Egypt: Coptic pope cancels Pence Meeting Over Jerusalem."

${ }^{49}$ G. Sale (2018), “Concerning Jerusalem as Capital,” La Civiltà Cattolica, Vol. 2, no. 4, pp. 9-20.
} 
The Palestinian Policy Network, Al-Shabaka, published a number of recommendations and views of Palestinian experts and academics as how to deal with the Trump Jerusalem's announcement. ${ }^{50}$ Nur Arafeh argued that Trump's announcement "supports Israel's system of apartheid and facilitate its ongoing Judaization of Jerusalem", calling on the PNA to end security coordination with Israel and withdraw from the Oslo Accords. Dana El Kurd noted that recognizing Jerusalem as Israel's capital would create two different legal frameworks in the city, one run by Israel which pays no respect to international law and one of the Palestinians. "[Trump's declaration] sets a precedent for greater legal recognition in the future," she wrote ${ }^{51}$ Munir Nuseibah asserted that the US Jerusalem move confirmed once again the US biased position in favor of Israel. "The only positive outcome is that it ends the illusion that the "peace process' is legitimate," he wrote. Victor Kattan and Tareq Baconi recommended paths for the PNA to follow to respond to the move. While Kattan outlined strategies the Palestinian leadership would adopt, including urging more countries to recognize the State of Palestine, Baconi called for the PNA to be re-formed in a way that would serve the Palestinian struggle, to avoid its collapse. $^{52}$

Jake Sullivan of the Carnegie Endowment for International Peace argued that it is "hard to find a good argument for the decision with respect to advancing the cause of peace in the Middle East. ${ }^{, 53}$ The RAND Corporation noted that such a decision will give a boost to radical forces in the region and will leave the US without allies, including its traditional allies such as Jordan, which had a very strong domestic backlash over the US move. RAND noted that US found itself isolated following its Jerusalem move, which resulted in losing its allies. The US think-tank noted that the US is risking inflaming regional tension which would result in more anti-American sentiment. The US move will result in boosting radical bodies and voices in the region such as Iran, noted RAND. ${ }^{54}$

The US move resulted in a wave of fury and anger in the OPTs. In Gaza, tens of thousands took part in protests against the US decision, which resulted in the death of dozens of Palestinians and the injury of hundreds of others. Palestinians took to the Gaza-Israel fence as part of the already existing Great March of Return, yet with huge numbers and much anger. ${ }^{55}$ In the West Bank, Palestinians took part in protests and sit-ins protesting the US move. While in Jerusalem, "US citizens and government employees were told to avoid Jerusalem's Old City and the West Bank until further notice." ${ }^{16}$ As expected, this anger over the US decision faded away as time passed on and moving the US embassy to Jerusalem became another fact on the ground Palestinians have to deal with.

In Israel, political and security circles chose strategic engagement and it was clear that Israeli national circles received the decision with a great deal of joy. In fact, Israeli Prime Minister Netanyahu tweeted expressing his profound gratefulness for the US move and Trump's "courageous and just decision." 7 The Israeli government decided to name a train stop in Jerusalem after Trump in celebration of his Jerusalem move, a decision which went into effect on May 15, 2019. ${ }^{58}$ The US recognition of Jerusalem as Israel's capital and its recognition of Israeli sovereignty over the Golan Heights has paved the way for the Israeli government to introduce a plan to annex parts of the West Bank by July 1, 2020. ${ }^{59}$

Overall, statements and speeches made in refusal of the US Jerusalem move were reactionary and lacked a concrete plan through which countries as well as peoples could pressure the US to change its position.

\footnotetext{
${ }^{50}$ Nur Arafeh et al. (2018), “Trump, Jerusalem, and the Future of Palestine," The Palestinian Policy Network, Shabaka, Palestine, 18 December 2018, https://goo.gl/9wQiCu (accessed on 10 January 2019).

${ }^{51}$ Nur Arafeh et al. (2018), "Trump, Jerusalem, and the Future of Palestine."

${ }^{52}$ Nur Arafeh et al. (2018), "Trump, Jerusalem, and the Future of Palestine."

53 Jake Sullivan (2017), “Trump's Jerusalem Decision,” the Carnegie Endowment for International Peace,” Washington, 9 December 2017, https://goo.gl/HCbyYv (accessed on 10 January 2019).

${ }^{54}$ Dalia Dassa Kaye (2018), "What to Make of Trump's Decision on Jerusalem," RAND Corporation, Washington, 28 December 2017, https://goo.gl/RUSYjg (accessed on 10 January 2019).

${ }_{55}$ M. Rapoport (2019), Between Jerusalem and Gaza: Why Unilateralism Will Not Work," Review of Middle East Studies, Vol. 53, no. 1, pp. 54-58.

${ }^{56}$ Spyros Sofos \& Vittorio Felci (2017), "What Trump's Recognition of Jerusalem as the Capital of Israel Means for the Middle East," The Conversation, 7 December 2017, https://theconversation.com/what-trumps-recognition-of-jerusalem-as-the-capital-of-israel-means-for-themiddle-east-88722 (accessed on 10 December 2019).

${ }^{57}$ Office of the Prime Minister of Israel (2018), (@IsraeliPM), Twitter (6 December 2017). https://goo.gl/FtCyHq (accessed on 20 December 2019).

${ }^{58}$ John Bowden (2017), "Israel to Officially Name Train Stop in Jerusalem for Trump Next Week," The Hill, Washington DC, 30 April 2017 , https://thehill.com/policy/international/441362-israel-to-name-train-stop-in-jerusalem-for-trump (accessed on 8 December 2019).

59 R. Cohen-Almagor (2017), "President Trump and the Israeli-Palestinian Conflict," E-International Relations, 10 March 2017, https:/www.e-ir.info/2017/03/10/president-trump-and-the-israeli-palestinian-conflict/ (accessed on 8 December 2019).
} 
The US, in addition to being impacted by domestic factors was aware of the situation in the Arab and Muslim world, which experiences much division. The following section addresses how the lack of unity among Arab governments and conflicts that have been sweeping the Arab World since 2011 have impacted Arab positions on the US move.

\section{Regional Politics in the Middle East and the US Relocation of Its Israel Embassy}

The regional developments in the region made it possible for the US to make such a decision without fearing future political or economic implications. In addition to the divided Palestinians, some countries in the Arab Gulf have signaled readiness to normalize relations with Israel before solving the IsraeliPalestinian conflict. The singing of the Oslo Accords in 1993 between the PLO and Israel made it easier for other Arab countries to normalize relations with Israel. Some Gulf countries started openly allowing Israeli planes in their airspace, ${ }^{60}$ while others have allowed the participation of Israeli sports and cultural teams in international forums held on their soil. ${ }^{61}$

Arab and Muslim countries, especially in the Middle East, have been fragmented and divided. The Gulf Cooperation Council (GCC), which has been the strongest Arab bloc, economically and politically, has been largely fragmented following the Gulf diplomatic crisis of $2017 .^{62}$ The environment for such a decision was in the interest of the US and Israel. The division among the Palestinians, the civil-war in Syria, the continuing conflicts in Iraq and Yemen, and the competition and cold war in the Middle East between various regional powers, all made it easier for Trump to make a decision without having to think about future implications. ${ }^{63}$ Arabs, let alone Palestinians, are no longer united and each party is worried about its domestic issues.

Palestinians, despite an agreement to end the rift in Cairo in October 2017, are still divided. Hamas controls Gaza and the PNA, which is led by Fatah, controls the West Bank. The US would have considered the Palestinian reaction to the decision differently had the Palestinians been united. The Palestinian society in the Gaza Strip and the West Bank has become fragile due to the division and the continuing Israeli policies which made the community vulnerable to many economic, social and political problems. ${ }^{64}$ Palestinians besieged in Gaza have lost their ability to move freely and most young people there are jobless. Conditions are dire also for Palestinians in the West Bank, who suffer from the growing violence of the Israeli army and settlers, in addition to the worsening economic conditions. ${ }^{65}$

Iran, which has intervened in some Arab countries such as Syria, Lebanon, Yemen, and Iraq is at cold war with the anti-Iran Arab block. As for Israel, Iran has always posed an existential threat to Israel, which means chances of rapprochement between the anti-Iran Arab block and Israel became much stronger. ${ }^{66}$ In the same context, Netanyahu has managed to convince US officials of the notion that the issue of nuclear Iran is more important to them than the Palestinian-Israeli conflict. ${ }^{67}$ It appeared that major Gulf countries, which have considerable weight economically and politically, became more interested in developing their relationship with Israel to achieve their own interests keeping in mind Iran's expansion in the region.

Reports suggested possible launch of diplomatic ties between Israel and more Arab countries. The Israeli Haaretz Newspaper has claimed that Israel is working to establish ties with more Arab countries, soon after it has established ties with Chad.$^{68}$ Bahrain has defended Australia's move to recognize West

\footnotetext{
60 S. Henderson \& A. Orion (2018), "Netanyahu Visits Oman," The Washington Institute, Policy Alert, https://www.washingtoninstitute.org/policy-analysis/view/netanyahu-visits-oman (accessed on 27 April 2020).

61 J. Dart (2017), "Israel and a sports boycott: Antisemitic? Anti-Zionist?," International review for the sociology of sport, Vol. 52, no. 2, pp. 164-188.

${ }^{62}$ C. Bianco \& G. Stansfield (2018), "The intra-GCC crises: mapping GCC fragmentation after 2011," International Affairs, Vol. 94, no. 3, pp. 613-635.

${ }^{63}$ F. Gregory Gause (2014), "Beyond Sectarianism: The New Middle East Cold War,” Brookings Doha Center, Analysis Paper 11, pp. 1-27. ${ }^{64}$ Nathan J. Brown (2010), “The Hamas-Fatah Conflict: Shallow but Wide,” Fletcher F. World Affairs, Vol. 34 , p. 35.

${ }^{65}$ I. Lavi et al. (2014), "Protected by ethos in a protracted conflict? A comparative study among Israelis and Palestinians in the West Bank, Gaza, and East Jerusalem," Journal of Conflict Resolution, Vol. 58, no. 1, pp. 68-92.

${ }^{66}$ K. A. Kebaish (2018), "Tiran and Sanafir: A Historical and Constitutional Argument Opposing the Territorial Cession of the Tiran and Sanafir Islands to Saudi Arabia," Texas Law Review, Vol. 97, p. 835.

${ }^{67}$ Khalidi (2018), “And Now What? The Trump Administration and the Question of Jerusalem," pp. 93-102.

${ }^{68}$ Noa Landau (2018), "Israel Working to Establish Diplomatic Ties With Sudan, Bahrain," Harretz Newspaper, Tel Aviv, November 25, 2018, https://goo.gl/jgEu3a (accessed on 20 December 2019).
} 
Jerusalem as Israel's capital in a statement made by its foreign affairs minister. ${ }^{69}$ This means that countries that were less likely to normalize relations with Israel have done so, which weakens the strategic position of the Palestinians. Additionally, Palestinians need the financial aid they get from countries in the Gulf, which further weakens their position.

The reason Arab and Muslim states started this wave of normalization with Israel could be attributed to various factors. Since 2007, Palestinians have been divided and all attempts to bring them together have failed so far. ${ }^{70}$ So, Arab countries no longer feel the urge to oppose Israeli policies against Palestinians who failed to have a united position against Israel. Another factor is the economic benefits Arab states, especially the Arab Gulf, might get if their relations with Israel are normalized. On the other hand, Israeli Prime Minister Benjamin Netanyahu has long advocated the idea of economic peace with Arabs in return for normalizing relations with Israel. One last factor to be considered is the Iranian factor. ${ }^{71}$ Arab states, especially in much of the Gulf, found in Iran, just like Israel does, their enemy. There is a common interest between some countries in the Arab Gulf and Israel to mitigate the Iranian influence in the region.

This has created a strategic situation in favor of Israel in the region which encouraged the US President Donald Trump to make such a decision, knowing that it will be faced by limited opposition or no opposition at all. Such summits and condemnations would not deter the US to reverse its Jerusalem embassy move. The Middle East has never been fragmented as it is today and the US President would not find a better time to relocate the US embassy without thinking of the possible implications of his move, if there are implications at all. Trump has made the Jerusalem move adopting the view of Mike Pence, US Vice President, and Sheldon Adelson, Trump's major electoral campaign donor. ${ }^{72}$

\section{Conclusion}

Trump has taken an unprecedented step by recognizing Jerusalem as the capital of Israel negating a tradition by all former US presidents who, in the past, signed a waver preventing the implementation of a law passed by the US congress in 1995 that recognizes Jerusalem as the capital of Israel and calls for relocating the US embassy from Tel Aviv to Jerusalem. Trump has carried out his electoral promise of moving the US embassy in Israel to Jerusalem. The domestic considerations, such as winning the support of the pro-Israel Republicans, the donations the Trump campaign has got from the pro-Israel donors, and Trump's attempt to win the support of the evangelical Christians, and the investigations against him in the US by the FBI, all contributed to his decision to relocate the US embassy.

Additionally, regionally, the Middle East has been engaged in civil wars following the outbreak of the Arab Spring in 2011, which resulted in weakening the structure of the regional system of Arab states, with more countries, especially in the Gulf, willing to normalize ties with Israel in return for economic benefits. Arab countries were less likely going to oppose or even oppose at all the US Jerusalem move. Arab and Muslim countries have produced reluctant statements explaining how harmful such a move would be to the peace process between the Palestinians and the Israelis. Following Iran's expansion in the Arab World, a strategic change in the favor of Israel in relation to the thinking of some Arab countries towards Israel in the region has taken place, with some Arab countries and Israel seeing in Iran their shared enemy.

Palestinians on the other hand have been divided with Fatah and Hamas failing to reach a reconciliation agreement. In the OPTs, Palestinians' reaction to Trump's decision was limited to protests that resulted in the killing of dozens of Palestinians in the Gaza Strip. Meanwhile, Israel has been going more towards the right, with right-wing figures given key ministries, who celebrated the US move as a long-awaited victory. Before resolving their deep political differences, Palestinians will not be able to face the US move and Israel will continue to have a stronger strategic position over them in which it will have the upper hand both intentionally and on the ground.

\footnotetext{
${ }^{69}$ Times of Israel (2018), "Bahrain Defends Australia’s Recognition of West Jerusalem as Israeli Capital,: Jerusalem, 10 December 2018, https://goo.gl/TnQnTX (accessed on 21 December 2019).

${ }^{70}$ Benoit Challand (2009), "Fatah-Hamas Rivalries after Gaza: Is Unity Impossible?," The International Spectator, Vol. 44, no. 3, pp. $11-17$.

${ }^{71}$ Yoel Guzansky (2011), "Tacit Allies: Israel and the Arab Gulf States," Israel Journal of Foreign Affairs, Vol. 5, no. 1, p. 9.

72 Josh Dawsey, Missy Ryan \& Karen DeYoung (2019), "Trump Had for Months Been Determined to Move U.S. Embassy to Jerusalem," The Washington Post, Washington DC, December 6, 2017, https://wapo.st/2YiboKm (accessed on 8 May 2019).
} 
All in all, the domestic situation in the US and the regional circumstances in the Middle East have facilitated the task of the US president and made future possible implications to Trump's decision less impactful and harmful given the reaction of the US allies in the region. More governments in the region today are willing to accept Israel as part of the system in the Middle East. Arab countries have been shaken by uprisings and economic crises that weakened their ability to respond to challenges and take a united position as they relatively used to do in the past. This division, which only got worse over the years, has served Israel and made Arab countries unable to take a unified position. This is clear in the representation of Arab governments in the Istanbul summit held to discuss the US move. This representation varied in strength based on regional and political considerations.

Yet, despite the US move, and the weak position of Arab governments, the world's countries have taken a united position of not moving their embassies to Jerusalem. Aside from Australia, which recognized Western Jerusalem as the capital of Israel, 128 countries voted in favor of a UN resolution condemning the US move. With the exception of Guatemala, no Latin American country expressed willingness to move its embassy to Jerusalem. It is worth mentioning that the right-wing president of Brazil, Jair Bolsonaro, has vowed to move his country's embassy to Jerusalem, a move he has not carried out yet. Both Brazil and Honduras have opened trade offices in Jerusalem. As for Paraguay, it has reversed its decision to relocate its embassy from Jerusalem to Tel Aviv, which caused much anger in Israel.

There is no possibility that the US will reverse its decision and relocate the US embassy to Tel Aviv in the future. Such a step would lead to a domestic crisis in the US especially in the US Congress. Such a move would harm the US-Israel strategic partnership. In other words, Trump's decision is likely irreversible and the strategic environment in the Middle East following the Arab Spring has been in favor of Israel. On the other hand, Palestinians find themselves more isolated in the Middle East, as Israel is expanding its diplomatic outreach in the region. Most recently, US democratic nominee for US elections, Joe Biden, said he will not move the US embassy back to Tel Aviv if elected, which means that the US embassy will most likely remain in Jerusalem in the short term, at least.

\section{References}

Abunimah, Ali (2006), One Country: A Bold Proposal to End the Israeli-Palestinian Impasse, New York: Metropolitan Books.

Abunimah, Ali (2018), "US Support for Israel Eroding, But Not Among Trump Voters, Poll Finds," Electronic Intifada, 26 October 2018, https://goo.gl/Gn6RwC (accessed on 20 December 2019).

Ackerman, Gwen \& Noueihed, Lin (2017), "Pence Faces Difficult Middle East Visit After Jerusalem Move," Bloomberg, US, 9 December 2017, https://goo.gl/JAhNE7 (accessed on 16 December 2019).

Aljamal, Y. М. (2014), "Hamas: Terrorism Organization or Liberation Movement?," Политикологија религије, Vol. 8, no. 1.

Al Zoughbi, Basheer (2016), "Trump's Plan to Move the US Embassy to Jerusalem," Aljazeera Center for Studies.

Aljazeera English (2017), "Egypt: Coptic Pope Cancels Pence Meeting Over Jerusalem," Aljazeera Network, Qatar, 2017 https://goo.gl/FLDuJw (accessed on 16 December 2019).

Aljazeera English (2017), "Hamas: US Decision on Jerusalem is A War Declaration," Aljazeera English, Qatar, 7 December 2017, https://goo.gl/JRQYCH (accessed 16 December 2019).

Arafeh, N., El Kurd, D., Nuseibah, M., Kattan, V. \& Baconi, T. (2018), "Trump, Jerusalem, and the Future of Palestine," The Palestinian Policy Network, Shabaka, Palestine, 18 December 2018, https://goo.gl/9wQiCu (accessed on 10 January 2019).

Belov, K. (2018), “Running for human rights in Palestine,” Green Left Weekly, Vol. 1202. 
Trump's Decision to Recognize Jerusalem as Israel's Capital

Bianco, C. \& Stansfield, G. (2018), "The intra-GCC crises: mapping GCC fragmentation after 2011," International Affairs, Vol. 94, no. 3.

Black, Ian (2018), "Donald Trump and the Middle East," Political Insight, Vol. 9, no. 1.

Bouris, Dimitris (2010), “The European Union's Role in the Palestinian Territory After the Oslo Accords: Stillborn State-building," Journal of Contemporary European Research, Vol. 6, no. 3, 376394.

Bowden, John (2017), "Israel to Officially Name Train Stop in Jerusalem for Trump Next Week," The Hill, Washington DC, 30 April 2017, https://thehill.com/policy/international/441362-israel-to-nametrain-stop-in-jerusalem-for-trump (accessed on 8 December 2019).

Breuning, M. (2007), Foreign policy analysis: A comparative introduction, New York City: Springer.

Brown, Nathan J. (2010), "The Hamas-Fatah Conflict: Shallow but Wide," Fletcher F. World Affairs, Vol. 34 , no. 2 .

Challand, Benoit (2009), "Fatah-Hamas Rivalries After Gaza: Is Unity Impossible?," The International Spectator, Vol. 44, no. 3.

Cooper, Rayan (2019), "What Donald Trump Has Said About Jews," The Week, the United States, 18 April 2019, https://theweek.com/articles/835714/what-donald-trump-said-about-jews (accessed on 17 May 2019).

Clifton, Eli (2017), "Is Sheldon Adelson Behind Trump's Decision on Jerusalem?" +972 Website, Tel Aviv, 5 December 2017, https://goo.gl/Umf6DK (accessed on 16 December 2019).

Cohen-Almagor, R. (2017), "President Trump and the Israeli-Palestinian Conflict," E-International Relations, 10 March 2017, https://www.e-ir.info/2017/03/10/president-trump-and-the-israelipalestinian-conflict/ (accessed on 8 December 2019).

Daniel, Zoe (2017), "Donald Trump: The Huge Israel Announcement Has Overshadowed the Russia Turmoil at Home," ABC News Network, Sydney, Australia, 8 December 2017, https://goo.gl/jmyNdJ (accessed on 16 December 2019).

Dart, J. (2017), "Israel and a sports boycott: Antisemitic? Anti-Zionist?," International review for the sociology of sport, Vol. 52, no. 2.

Dawsey, J., Ryan, M. \& DeYoung, K. (2017), “Trump Had for Months Been Determined to Move U.S. Embassy to Jerusalem," The Washington Post, Washington DC, 6 December 2017, https://wapo.st/2YiboKm (accessed on 8 May 2019).

Eriksson, Jacob (2018), "Master of None: Trump, Jerusalem and the Prospects of Israeli-Palestinian Peace," Middle East Policy, Vol. 25, no. 2.

Gause, F. Gregory (2014), "Beyond sectarianism: The New Middle East Cold War," Brookings Doha Center Analysis Paper 11.

Galbraith, J. (2019), "Palestine brings a case against the United States in the international court of justice at a fraught time for US-Palestinian relations," American Journal of International Law, Vol. 113, no. 1 .

Guzansky, Yoel (2011), "Tacit Allies: Israel and the Arab Gulf States," Israel Journal of Foreign Affairs, Vol. 5, no. 1.

Kebaish, K. A. (2018), "Tiran and Sanafir: A Historical and Constitutional Argument Opposing the Territorial Cession of the Tiran and Sanafir Islands to Saudi Arabia," Texas Law Review, Vol. 97. 
Habiballah, N. (2016), "The Unmaking of Arab Jerusalem through Settlement Construction," Jerusalem Quarterly, Vol. 65, 111-117.

Hamid, S. (2017), “The Jerusalem Announcement Won't Really Hurt America's Arab Alliances," Brookings Institution.

Henderson, S. \& Orion, A. (2018), "Netanyahu Visits Oman," The Washington Institute, Policy Alert, https://www.washingtoninstitute.org/policy-analysis/view/netanyahu-visits-oman (accessed on 27 April 2020).

Hodgkins, A. (2017), "Relocating the US Embassy in Israel: A cost benefit analysis for Trump administration," American Diplomacy.

Kattan, V. (2018), "Why US recognition of Jerusalem could be contrary to international law," Journal of Palestine Studies, Vol. 47, no. 3.

Kaye, Dalia Dassa (2017), "What to Make of Trump's Decision on Jerusalem," RAND Corporation, Washington, 28 December 2017, https://goo.gl/RUSYjg (accessed on 10 January 2019).

Kontos, M. (2002), US Middle East Strategy under President Trump's Isolationist Foreign Policy, University of Nicosia.

Khalidi, Rashid I. (2018), "And Now What? The Trump Administration and the Question of Jerusalem," Journal of Palestine Studies, Vol. 47, no. 3.

Walid, Khalidi (1997), "Revisiting the UNGA partition resolution," Journal of Palestine Studies, Vol. 27, no. 1.

Landau, Noa (2018), "Israel Working to Establish Diplomatic Ties With Sudan, Bahrain, Haaretz Newspaper, Tel Aviv, 25 November 2018, https://goo.gl/jgEu3a (accessed on 20 December 2019).

Landler, Mark (2017), "For Trump, an Embassy in Jerusalem Is a Political Decision, Not a Diplomatic One", New York Times, 6 December 2017, https://goo.gl/GD6iCD (accessed on 2 December 2019).

Lavi, I., Canetti, D., Sharvit, K., Bar-Tal, D. \& Hobfoll, S.E. (2014), "Protected by ethos in a protracted conflict? A comparative study among Israelis and Palestinians in the West Bank, Gaza, and East Jerusalem," Journal of Conflict Resolution, Vol. 58, no. 1.

Lucentini, Mauro (2016), "The Outlook for US foreign Policy Under President Donald J. Trump," Rivista di Studi Politici Internazionali, Vol. 83, no. 4.

Masrawi News Website (2017), "Statement by President Abbas on Jerusalem," Cairo, 6 December 2017, https://goo.gl/tAC7zs (accessed on 16 December 2019).

Moten, A. R. (2018), "US Embassy in Jerusalem: Reasons, Implications and Consequences," Intellectual Discourse, Vol. 26, no. 1.

Oxford Analytica (2020), Gantz paves the way for an Israeli unity coalition, Emerald Expert Briefings.

Office of the Prime Minister of Israel (2018), (@IsraeliPM), Twitter (6 December 2017), https://goo.gl/FtCyHq (accessed on 20 December 2019).

Sofos, Spyros \& Felci, Vittorio (2017), ““'What Trump's Recognition of Jerusalem as the Capital of Israel Means for the Middle East," The Conversation, 7 December 2017, https://theconversation.com/what-trumps-recognition-of-jerusalem-as-the-capital-of-israel-means-forthe-middle-east-88722 (accessed on 10 December 2019). 
Rapoport, M. (2019), "Between Jerusalem and Gaza: Why Unilateralism Will Not Work," Review of Middle East Studies, Vol. 53, no. 1.

Sternhell, Zeev (2017), "Jerusalem as the Basis of a Binational State," Haaretz Newspaper, Tel Aviv, 16 December 2017, https://goo.gl/x43Ww4 (accessed on 16 December 2019).

Sullivan, Jake (2017), "Trump's Jerusalem Decision," Carnegie Endowment for International Peace," Washington, 9 December 2017, https://goo.gl/HCbyYv (accessed on 10 January 2019).

Telhami, Shibley (2018), "Why is Trump Undoing Decades of US Policy on Jerusalem?," The Washington Report on Middle East Affairs, Vol. 37, no. 1.

The United Nations (1948), Israel membership in the UN - Letter from Israel. The United Nations: The Question of Palestine, 29 November 1948, https://www.un.org/unispal-/document/auto-insert-176869/ (accessed on 6 June 2020).

Times of Israel (2018), "Bahrain Defends Australia's Recognition of West Jerusalem as Israeli Capital," Jerusalem, 10 December 2018, https://goo.gl/TnQnTX (accessed on 21 December 2019).

Usher, G. (2006), “The democratic resistance: Hamas, Fatah, and the Palestinian elections," Journal of Palestine Studies, Vol. 35, no. 3.

Verter, Yossi (2017), "With Jerusalem Recognition, Trump Gives Netanyahu a Great Tool to Distract the Masses," Haaretz Newspaper, Tel Aviv, 7 December 2017, https://goo.gl/eCUCH5 (accessed on 16 December 2019).

WAFA (2017), "The National Committee: U.S. Embassy Move Is the Wrong Move," WAFA: Palestinian News and Info Agency, 19 January 2017, https://goo.gl/NkDt4A (accessed 16 April 2019).

White House (2017), "Statement by President Trump on Jerusalem," Statements and Release, the White House, Washington DC, 6 December 2017, https://goo.gl/R8opkp (accessed on 15 December 2019).

Wilkinson, Tracy (2017), "Heads of Christian churches in Jerusalem Urge Retaining City's 'International Status'," Los Angeles, US, 6 December 2017, https://goo.gl/SmQqw1 (accessed 16 December 2019).

Zanotti, J. (2018), "US Foreign Aid to the Palestinians," Current Politics and Economics of the Middle East, Vol. 9, no. 4. 
Journal of Al-Tamaddun, Vol. 15 (1), 2020, 119-131 